\title{
Stem Cell Therapy for Blood Cancer
}

Armel Herve Nwabo Kamdje ${ }^{1 *}$ and Paul Faustin Seke Etet ${ }^{2}$

${ }^{1}$ Department of Biomedical Sciences, University of Ngaoundere-Cameroon, Cameroon

${ }^{2}$ Department of Basic Health Sciences, College of Applied Medical Sciences, Qassim University, Buraydah, 51452, Al-Qaseem, Saudi Arabia

\section{Introduction}

In the last decade, many reports have emphasized the potential of stem/precursor cells as intervention strategy to repair damaged tissue, providing new hope in the scientific and medical community for the treatment of various diseases and conditions considered as incurable before, such as neurodegenerative disorders $[1,2]$, celiac disease $[3,4]$, type 1 diabetes mellitus complications $[5,6]$, muscle damage $[7,8]$ and various blood cancers. Overall, experimental and clinical evidence shows that embryonic stem cells and, in a lesser extent, adult stem cells can generate various tissue types with the potential to replace damaged areas in the body, with a reduced risk of rejection and manageable side effects. These findings have opened new avenues for cell-based cancer therapies, whose majority are at experimental stage. These strategies are providing very encouraging results, particularly in clonal hematopoietic disorders like Myelodysplastic Syndromes (MDS) where the bloodforming cells damaged in the bone marrow are successfully repaired by Hematopoietic Stem Cell (HSC) transplantation with minimal toxicity and improved quality of life [9]. However, due to the complexity of blood cancer pathogenesis and clinical features also shared by MDS, many patients remain non-eligible for HSC transplantation or do not show any improvement following such treatment [10,11], pointing out the need for more research to understand stem cell behavior upon transplantation, particularly the interactions with the diseased hematopoietic niche.

Many laboratories are addressing this issue and are currently studying how stem cell can be used for blood cancer treatment. Interestingly, Song et al. [12] have reported that in the bone marrow of MDS patients, although HSCs and Mesenchymal Stem/Stromal Cells (MSCs) display cytogenetic aberrations, MSCs are particularly affected by chromosomal aberrations with a random loss of chromosomal material. Bone marrow MSCs (BM-MSCs) are multilineage non hematopoietic progenitor cells derived from mesodermal precursors, which play a key role in supporting hematopoiesis and that give rise to different stromal cell lineages $[13,14]$. The findings of Song et al. [12] suggesting an enhancement of genetic susceptibility of BMMSCs in MDS patients indicate that genetic alterations in these cells may constitute a key mechanism in the pathogenesis of MDS and of subsequent more aggressive cancers like acute myeloid leukemia. BMMSCs express various proto-oncogenes which have been reported as crucial for HSC maintenance like Notch ligands and Wnt $[15,16]$; MSC-derived osteoblasts regulate the HSC niche through Jagged-1/ Notch-1 signaling [17]; and BM-MSCs have been reported to play a pivotal role in the survival of Acute Lymphoblastic Leukemia (ALL) and chronic lymphoblastic leukemia B-cells $[18,19]$. In addition to the genetic aberrations affecting BM-MSCs and to the release or expression of oncogenes, the latter cells would determine the onset of high-risk MDS by displaying poor ability of hematopoietic support and immunosuppressive abilities [20]. These observations may explain at least in part the improvement of the condition of some MDS patients following bone marrow transplantation, i.e. an adjunction of healthy BM-MSCs that probably rescues BM-MSC cell populations and restores hematopoietic support. Beside bone marrow or HSC transplantation, other approaches aiming at restoring the HSC niche are being tested, including the promising peripheral blood stem cell transplantation.

The purpose of this special issue is to communicate and present some of the latest research carried out in this area while reviewing other important recent developments in the field.

\section{References}

1. Reilmann R (2012) An important step towards translation of stem cell therapies in clinical applications for neurodegenerative diseases and beyond? Mov Disord 27: 1355-1356.

2. Liu SP, Fu RH, Huang SJ, Huang YC, Chen SY, et al. (2012) Stem Cell Applications in Regenerative Medicine for Neurological Disorders. Cell Transplant.

3. Kline RM, Neudorf SM, Baron HI (2007) Correction of celiac disease after allogeneic hematopoietic stem cell transplantation for acute myelogenous leukemia. Pediatrics 120: e1120-e1122.

4. lacob R, Sirbu-Boeti P, lacob S, Dima S, Gheorghe C, et al. (2009) Stem cells therapies for gastrointestinal and liver diseases. Chirurgia (Bucur) 104: 131140.

5. Dominguez-Bendala J, Lanzoni G, Inverardi L, Ricordi C (2012) Concise review: mesenchymal stem cells for diabetes. Stem Cells Trans Med 1: 59-63.

6. Hu J, Yu X, Wang Z, Wang F, Wang L, et al. (2012) Long term effects of the implantation of Wharton's jelly-derived mesenchymal stem cells from the umbilical cord for newly-onset type 1 diabetes mellitus. Endocr J.

7. Gharaibeh B, Chun-Lansinger $\mathrm{Y}$, Hagen T, Ingham SJ, Wright V, et al. (2012) Biological approaches to improve skeletal muscle healing after injury and disease. Birth Defects Res C Embryo Today 96: 82-94.

8. Bernstein HS, Srivastava D (2012) Stem cell therapy for cardiac disease Pediatr Res 71: 491-499.

9. Mufti GJ, Potter V (2012) Myelodysplastic syndromes: who and when in the course of disease to transplant. Hematology. Am Soc Hematol Educ Program 2012: 49-55

10. Kantarjian HM, Thomas XG, Dmoszynska A, Wierzbowska A, Delaunay J et al. (2012) Multicenter, randomized, open-label, phase III trial of decitabine versus patient choice, with physician advice, of either supportive care or lowdose cytarabine for the treatment of older patients with newly diagnosed acute myeloid leukemia. J Clin Oncol 30: 2670-2677.

11. Oki Y, Kondo Y, Yamamoto K, Ogura M, Kasai M, et al. (2012) Phase I/II study of decitabine in patients with myelodysplastic syndrome: a multi-center study in Japan. Cancer Sci 103: 1839-1847.

12. Song LX, Guo J, He Q, Yang LP, Gu SC, et al. (2012) Bone marrow mesenchymal stem cells in myelodysplastic syndromes: cytogenetic characterization. Acta Haematol 128: 170-177.

*Corresponding author: Armel Herve Nwabo Kamdje, PhD, Department of Biomedical Sciences, University of Ngaoundere-Cameroon, Cameroon, E-mail: armel.nwabo@gmail.com

Received December 15, 2012; Accepted December 17, 2012; Published December 18, 2012

Citation: Kamdje AHN, Etet PFS (2013) Stem Cell Therapy for Blood Cancer. Blood Lymph S2:e001. doi:10.4172/2165-7831.S2-e001

Copyright: (c) 2013 Kamdje AHN, et al. This is an open-access article distributed under the terms of the Creative Commons Attribution License, which permits unrestricted use, distribution, and reproduction in any medium, provided the original author and source are credited. 
13. Pittenger MF, Mackay AM, Beck SC, Jaiswal RK, Douglas R, et al. (1999) Multilineage potential of adult human mesenchymal stem cells. Science 284 143-147

14. Phinney DG, Prockop DJ (2007) Concise review: mesenchymal stem/ multipotent stromal cells: the state of transdifferentiation and modes of tissue repair--current views. Stem Cells 25: 2896-2902.

15. Nwabo Kamdje AH, Mosna F, Bifari F, Lisi V, Bassi G, et al. (2011) Notch-3 and Notch-4 signaling rescue from apoptosis human B-ALL cells in contact with human bone marrow-derived mesenchymal stromal cells. Blood 118: 380-389.

16. Seke Etet PF, Vecchio L, Kamga PB, Nukenine EN, Krampera M, et al. (2013) Normal hematopoiesis and hematologic malignancies: Role of canonical Wn signaling pathway and stromal microenvironment. Biochim Biophys Acta 1835: $1-10$.
17. Calvi LM, Adams GB, Weibrecht KW, Weber JM, Olson DP, et al. (2003) Osteoblastic cells regulate the haematopoietic stem cell niche. Nature 425 841-846.

18. Nwabo Kamdje AH, Bassi G, Pacelli L, Malpeli G, Amati E, et al. (2012) Role of stromal cell-mediated Notch signaling in CLL resistance to chemotherapy. Blood Cancer J 2: e73.

19. Seke Etet PF, Vecchio L, Nwabo Kamdje AH (2012) Interactions between bone marrow stromal microenvironment and B-chronic lymphocytic leukemia cells: any role for Notch, Wnt and Hh signaling pathways? Cell Signal 24: 1433-1443.

20. Zhao Z, Wang Z, Li Q, Li W, You Y, et al. (2012) The different immunoregulatory functions of mesenchymal stem cells in patients with low-risk or high-risk myelodysplastic syndromes. PLoS.One 7: e45675. 